\title{
Complications associated with the use of silicone oil: A systematic review
}

\section{Complicaciones asociadas al uso de aceite de silicona: revisión sistemática}

\author{
Andreas Di Luciano ${ }^{1 *}$, Agustina Adaniya1 ${ }^{1}$, Rosa Alvarado-Villacorta², Djorge Velickovich ${ }^{3}$, \\ Virgilio Morales-Cantón ${ }^{1}$, and Jose A. Roca ${ }^{4}$ \\ ${ }^{1}$ Department of Retina, Asociación para Evitar la Ceguera en México, I.A.P., Mexico City, Mexico; ${ }^{2}$ Research Unit, Clínica Vista, Lima, Peru; ${ }^{3}$ Fundación \\ Visión, Asunción, Paraguay; ${ }^{4}$ Oftalmólogos Contreras, Lima, Peru
}

\begin{abstract}
Purpose: To identify and assess the available information regarding the frequency of complications following the use of silicone oil (SO). Methods: A systematic search was conducted in PubMed/Medline, Cochrane and Embase, up to June 2020. The reference lists of identified studies and relevant reviews were also reviewed. We included studies in Spanish and English, with no publication date limits, of all types of methodology, with populations over 50 eyes, with patients previously diagnosed with tractional retinal detachment, proliferative diabetic retinopathy, giant retinal tears, traumatic retinal detachment and patients with proliferative vitreoretinopathy from any cause, with a minimum follow-up of 6 weeks. The quality assessment of the studies was conducted according to the Centre for Evidence-Based Medicine classification of levels of evidence. Results: $A$ total of 13 studies were included, most of which were retrospective, with a level of evidence $2 b$. Cataract (median: 90, interquartile range [IQR]: 80-100\%), silicone oil emulsification in the anterior chamber (median: 64.5; IQR: 46.5-82.25\%), ocular hypertension (median: 23.3; IQR: 22.15-35.1\%) and retinal redetachment (median: 22; IQR: 18.5-30\%) were the most frequent complications; while pupillary block (median: 4.3; IQR: 3.8-4.8\%), subconjunctival silicone oil deposits (median: 4.15; IQR: 3.75-4.57\%), and expulsive suprachoroidal hemorrhage (median: 1; IQR: 0.95-1.05\%) were the least frequent. Conclusions: The most frequent complications reported in decreasing order were cataracts, silicone oil emulsification in the anterior chamber, ocular hypertension, retinal redetachment, keratopathy, hypotonia, subretinal silicone oil migration, rebleeding, secondary glaucoma, unexplained visual loss, pupillary block, subconjunctival silicone oil deposits and expulsive suprachoroidal hemorrhage.
\end{abstract}

Key words: Silicone oil complications. Silicone oil removal. Systematic review.

\section{Resumen}

Objetivo: Identificar y evaluar la información disponible sobre la frecuencia de las complicaciones tras el uso del aceite de silicona. Método: Se realizó una búsqueda sistemática en PubMed/Medline, Cochrane y Embase, hasta junio de 2020. Las listas de referencias de los estudios identificados y de las revisiones relevantes también fueron revisadas. Se incluyeron estudios en español e inglés, sin límite de fecha de publicación, de cualquier metodología, con una muestra mayor de 50 ojos, con pacientes con diagnóstico previo de desprendimiento de retina traccional, retinopatía diabética proliferativa, des-

520 8th avenue, $12^{\text {th }}$ floor Date of reception: 03-05-2020

Nueva York 10018, United States Date of acceptance: 22-08-2020

E-mail: andreasdilu@gmail.com
Available online: $16-03-2021$

Rev Mex Oftalmol (Eng). 2021;95(2):73-80

www.rmo.com.mx 2604-1731/@ 2020 Sociedad Mexicana de Oftalmología. Published by Permanyer. This is an open access article under the CC BY-NC-ND license (http://creativecommons.org/licenses/by-nc-nd/4.0/). 
garros gigantes, desprendimiento de retina, por trauma, y pacientes con proliferación vitreorretiniana independientemente de la causa, con un seguimiento mínimo de 6 semanas. La evaluación de la calidad de los estudios se realizó según la clasificación del Centre for Evidence-Based Medicine. Resultados: Se incluyeron 13 estudios, la mayoría retrospectivos, con un nivel de evidencia 2b. La catarata (mediana: 90; rango intercuartílico [RIC]: 80-100\%), la emulsificación en la cámara anterior (mediana: 64.5; RIC: 46.5-82.25\%), la hipertensión ocular (mediana: 23.3; RIC: 22.15-35.1\%) y el redesprendimiento de retina (mediana: 22; RIC: 18.5-30\%) fueron las complicaciones más frecuentes, mientras que el bloqueo pupilar (mediana: 4.3; RIC: 3.8-4.8\%), el depósito conjuntival de aceite de silicona (mediana: 4.15; RIC: 3.75-4.57\%) y la hemorragia expulsiva (mediana: 1; RIC: $0.95-1.05 \%$ ) fueron las menos reportadas. Conclusiones: Las complicaciones más frecuentes en orden decreciente fueron cataratas, emulsificación en la cámara anterior, hipertensión ocular, redesprendimiento de retina, queratopatía, hipotonía, migración de aceite de silicona subretinal, resangrado, glaucoma secundario, pérdida visual inexplicable, bloqueo pupilar, depósitos conjuntivales de aceite de silicona y hemorragia expulsiva.

Palabras clave: Complicaciones por aceite de silicón. Retiro de aceite de silicón. Revisión sistemática.

\section{Introduction}

The use of silicone oil (SO) in the vitreous cavity dates back to the late 1950s, when Stone ${ }^{1}$ showed in rabbit eyes that oils of different viscosities were well tolerated for a period of 2 years. The first human study was conducted in the early 1960 s by Cibis, et al. ${ }^{2}$, who used SO in 33 patients as retinal tamponade, demonstrating good retinal tolerance for a period of 7 months. Since then, the use of SO has been preferred for those cases with a high risk of retinal redetachment (reRD), such as complex retinal detachments associated with proliferative vitreoretinopathy (PVR), giant tears (GT) and tractional retinal detachments (TRD) associated with proliferative diabetic retinopathy (PDR), trauma or viral retinitis ${ }^{3}$.

$\mathrm{SO}$ is an important tool in vitreoretinal surgery because it has the ability to displace aqueous humor and maintain retinal adhesion; furthermore, it is a good tamponade agent for retinal lesions without traction. Although its use today is associated with good anatomical results, several complications have also been described that can affect almost all ocular structures and include cataract formation, ocular hypertension (OHT), anterior chamber oil emulsification, secondary glaucoma, reRD, hypotonia, pupillary block, SO subretinal migration, unexplained visual loss, subconjunctival deposits of $\mathrm{SO}$, rebleeding and expulsive hemorrhage ${ }^{3-30}$. The frequency of these complications varies considerably between different studies, and they can have a great impact on the visual health of the patient. Another important consideration in the use of SO is the need for an additional surgical procedure for its removal once the anatomical stabilization of the retina has been achieved; however, to date there is no consensus regarding the appropriate time to remove $\mathrm{SO}$ based on possible complications ${ }^{10-17}$. Considering the diversity and severity of the complications reported, as well as the heterogeneity of the existing reports, we decided to conduct a systematic review to assess the frequency of complications after the use of SO.

\section{Methods}

\section{Search strategy and selection of studies}

A systematic search was carried out in the PubMed/ Medline, Cochrane and Embase of publications up to June 2020, using the keywords "silicone oil removal", "outcome of silicone oil removal" and "silicone oil complications". Additionally, the reference list of identified studies and relevant reviews on the subject were assessed, looking for other possible studies that could be included.

Randomized clinical trial studies, cohort studies and case series were included, with a sample of more than 50 eyes, in patients with a previous diagnosis of TRD due to PDR, GT or trauma, and patients with PVR regardless of the cause, with a minimum follow-up of 6 weeks. Duplicate studies and those with incomplete data were excluded. Regarding language, studies in Spanish and English were searched, without limitation by publication date. The evaluation of the quality of the studies was carried out according to the classification of the Oxford Centre for Evidence-Based Medicine (OCEBM). Study selection was made independently by two investigators (AD and DV) and differences were resolved by a third investigator (AA).

\section{Data extraction and analysis}

The studies were exported to the EndNote X9 software to eliminate duplicate articles and subsequently imported to Number v6.1 6369 for tabulation. The data 


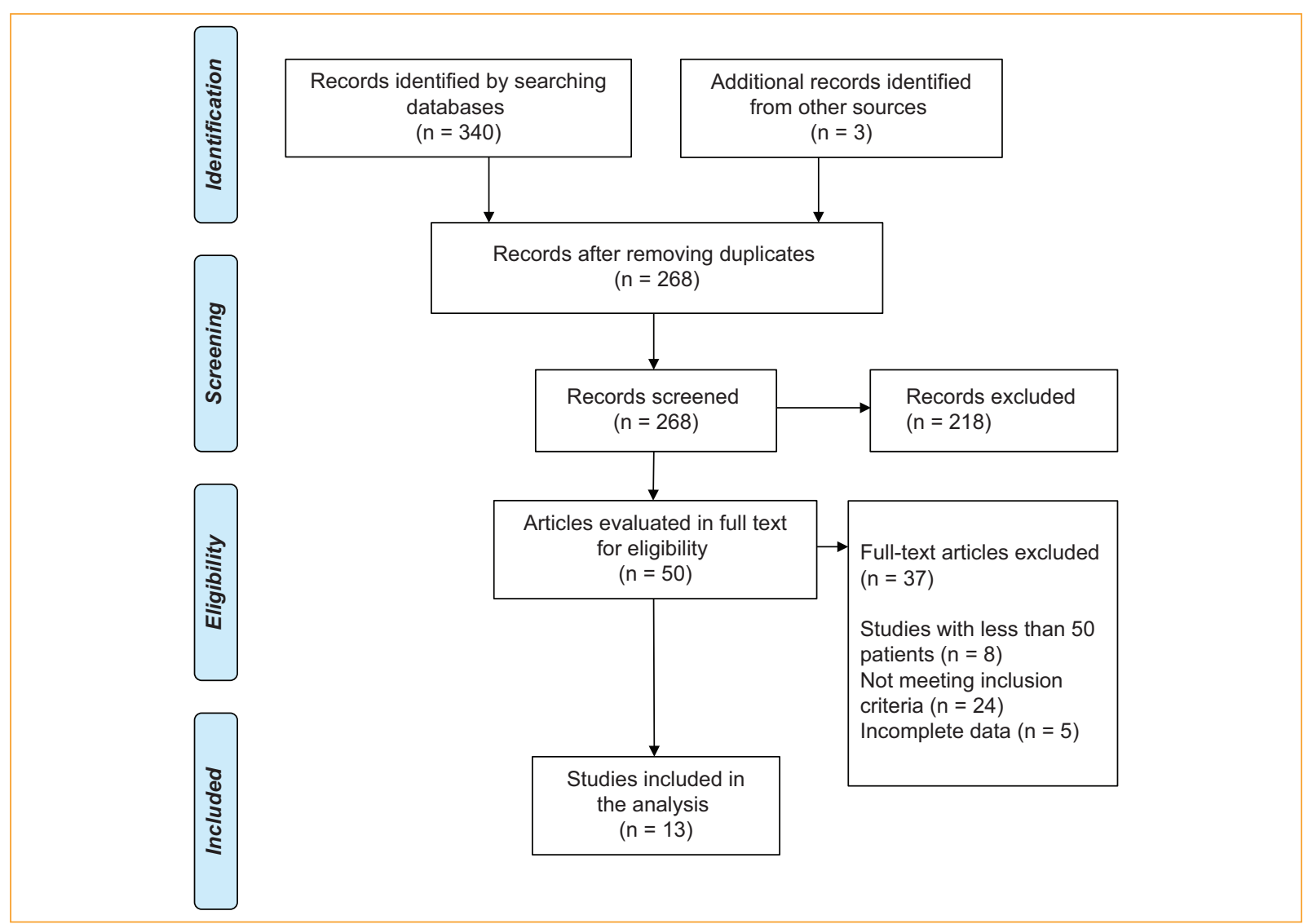

Figure 1. Flow chart for inclusion of studies in the systematic review according to PRISMA recommendations.

extracted from the studies were the main author, the year of publication, the country of origin, the methodology, the number of patients, age, sex, the type of SO, the most frequent indications, the time elapsed for SO removal and complications.

The data were independently reviewed by three investigators $(A D, D V$ and $A A)$. If there were any observations about one of the studies, it was further evaluated by another investigator (JR). The review was then again evaluated again by experts in the subject (VM and JR) before creating the final manuscript.

Data were grouped in descriptive tables using Numbers v6.1 6369 software (Apple Inc.). Categorical variables were expressed as percentages, and numerical results as mean and standard deviation or as median and interquartile range (IQR). Given the heterogeneity of the studies, no meta-analysis was performed.

\section{Results}

The search strategy identified 343 studies, of which 75 were eliminated due to duplication. During the title and abstract review, we found 50 potential studies. Finally, after the full texts, 13 articles were included for review (Fig. 1). Most of the articles corresponded to reports from the United States of America and Germany; in all cases, 1,000- or 5,000-centistoke SO was used. Only one randomized clinical trial was identified; most of the studies were retrospective, with a level of evidence $2 b$ according to the OCEBM classification. The characteristics of the studies included in the analysis are summarized in Table 1.

The complications after the use of SO reported are described in Table 2, and the most frequent were cataracts with a median of 90 (IQR: $80-100 \%$ ), anterior chamber oil emulsification with a median of 64.5 (IQR: 46.5-82.25\%), OHT with a median of 23.3 (IQR: 22.15$35.1 \%)$ and reRD with a median of 22 (IQR: $18.5-30 \%$ ). On the other hand, among the less frequent were pupillary block with a median of 4.3 (IQR: 3.8-4.8\%), subconjunctival deposits of SO with a median of 4.15 (IQR: $3.75-4.57 \%$ ) and finally expulsive hemorrhage with a median of 1 (IQR: $0.95-1.05 \%)$. 
Table 1. Main characteristics of the included studies and levels of evidence according to the Oxford Center for Evidence-Based Medicine (OCEBM) ( $\mathrm{n}=13$ )

\begin{tabular}{|c|c|c|c|c|c|c|c|c|c|c|}
\hline Studies & Country & Design: & Population & Age & Sex & SO type & Indications for surgery & Follow-up time & SO removal interval & $\begin{array}{l}\text { OCEBM } \\
\text { grading }\end{array}$ \\
\hline $\begin{array}{l}\text { Casswell, } \\
\text { et al. } .^{0} \text { (1987) }\end{array}$ & England & $\begin{array}{l}\text { Retrospective } \\
\text { (cohort) }\end{array}$ & $\begin{array}{l}85 \text { eyes } \\
\text { (85 patients) }\end{array}$ & NS & NS & NS & $\begin{array}{l}\text { GT: } 59(69.4 \%) \\
\text { PVR: } 26(30.58 \%)\end{array}$ & 18 months & $\begin{array}{l}\text { G1: } \bar{X}=9.1 \text { (3-20 } \\
\text { weeks) } \\
\text { G2 glaucoma: } \\
\bar{X}=20.2 \text { (3-60 weeks) } \\
\text { G2 keratopathy: } \\
\bar{X}=76 \text { (16-160 weeks) }\end{array}$ & $2 b$ \\
\hline $\begin{array}{l}\text { Lucke, et al. }{ }^{36} \\
\text { (1987) }\end{array}$ & Germany & $\begin{array}{l}\text { Retrospective } \\
\text { (cohort) }\end{array}$ & $\begin{array}{l}500 \text { eyes } \\
\text { (486 patients) }\end{array}$ & $46(1.5-85)$ & $\begin{array}{l}\text { M: } 311(62 \%) \\
\text { W: } 189(38 \%)\end{array}$ & $5000 \mathrm{cSt}$ & $\begin{array}{l}\text { PVR: } 55 \% \\
\text { GT: } 15 \% \\
\text { Posterior ruptures: } 14.6 \% \\
\text { PDR + TRD: } 18 \% \\
\text { Trauma: } 7.9 \%\end{array}$ & 15.7 months & 6-18 months & $2 b$ \\
\hline $\begin{array}{l}\text { Federman and } \\
\text { Schubert }{ }^{15} \\
\text { (1988) }\end{array}$ & United States & $\begin{array}{l}\text { Retrospective } \\
\text { (cohort) }\end{array}$ & $\begin{array}{l}150 \text { eyes } \\
\text { ( } 170 \text { patients) }\end{array}$ & $40-60$ years & NS & NS & $\begin{array}{l}\text { PVR C3 or worse: } 68.66 \% \\
\text { PDR + TRD: } 21.33 \% \\
\text { GT: } 5.3 \%\end{array}$ & $\begin{array}{c}\bar{X}=31.6 \\
\text { months } \\
(6 \text { months- } \\
5 \text { years })\end{array}$ & 3-6 months & $2 b$ \\
\hline $\begin{array}{l}\text { Riedel, et al. }{ }^{31} \\
(1990)\end{array}$ & Germany & $\begin{array}{l}\text { Retrospective } \\
\text { (cohort) }\end{array}$ & $\begin{array}{l}415 \text { eyes } \\
\text { ( } 415 \text { patients) }\end{array}$ & NS & NS & $5000 \mathrm{cSt}$ & $\begin{array}{l}\text { PVR due to RD: } 49 \% \\
\text { PVR due to trauma: } 13 \% \\
\text { PDR + TRD: } 38 \%\end{array}$ & 30 months & $6-30$ months & $2 b$ \\
\hline $\begin{array}{l}\text { Franks and } \\
\text { Leaver }{ }^{11} \text { (1991) }\end{array}$ & Germany & $\begin{array}{l}\text { Retrospective } \\
\text { (cohort) }\end{array}$ & $\begin{array}{l}120 \text { eyes } \\
\text { (116 patients) }\end{array}$ & $41.5(12-81)$ & NS & $1000 \mathrm{cSt}$ & $\begin{array}{l}\text { GT: } 47.5 \% \\
\text { Posterior tears: } 13.3 \% \\
\text { PVR: } 38.33 \%\end{array}$ & 5 years & $\begin{array}{l}\bar{X}=30 \text { ( } 3 \text { weeks- } \\
5 \text { years) }\end{array}$ & $2 b$ \\
\hline $\begin{array}{l}\text { Silicon Study } \\
\text { Group } \\
\text { (1992-1994) }\end{array}$ & United States & RCT & $\begin{array}{l}101 \text { eyes } \\
\text { (101 patients) }\end{array}$ & $66.2(24-84)$ & $\begin{array}{l}\text { M: } 17(33 \%) \\
\text { W: } 30(67 \%)\end{array}$ & $1000 \mathrm{cSt}$ & RRD + PVR $(100 \%)$ & 36 months & 8 weeks- 6 months & $1 \mathrm{~b}$ \\
\hline $\begin{array}{l}\text { Scholda, } \\
\text { et al. }{ }^{17}(2000)\end{array}$ & Austria & $\begin{array}{l}\text { Prospective } \\
\text { (cohort) }\end{array}$ & $\begin{array}{l}112 \text { eyes } \\
\text { (106 patients) }\end{array}$ & $\begin{array}{l}\text { RD group: } \\
44.2 \pm 21.4 \\
\text { No } R D \text { group: } \\
50.9 \pm 19.5\end{array}$ & NS & $\begin{array}{l}1000 \mathrm{cSt} \\
(\mathrm{n}=26) \\
5000 \mathrm{cSt} \\
(\mathrm{n}=86)\end{array}$ & $\begin{array}{l}\text { PVR }(n=59), \text { PDR }(n=34) \\
\text { Macular hole, IFB, CRV0, } \\
\text { uveitis, retinal hemangioma } \\
(n=19)\end{array}$ & $\begin{array}{c}7 \text { days- } 6.9 \\
\text { years }\end{array}$ & $\begin{array}{l}\text { RD group: } 185 \pm 94.5 \\
\text { days } \\
\text { No RD group: } 319 \pm \\
235 \text { days }\end{array}$ & $1 \mathrm{~b}$ \\
\hline $\begin{array}{l}\text { Falkner, et al. }{ }^{12} \\
(2001)\end{array}$ & Austria & $\begin{array}{l}\text { Retrospective } \\
\text { (cohort) }\end{array}$ & $\begin{array}{l}115 \text { eyes } \\
\text { (115 patients) }\end{array}$ & $54.9(13-83)$ & NS & 5000 cSt. & $\begin{array}{l}\text { RRD + PVR: } 89.2 \% \\
\text { TRD: } 5.4 \% \text {; trauma } 5.4 \%\end{array}$ & $\begin{array}{c}6 \text { months-3.5 } \\
\text { years }\end{array}$ & 13.3 months & $2 b$ \\
\hline $\begin{array}{l}\text { Moya, et al. } .^{20} \\
\text { (2015) }\end{array}$ & England & $\begin{array}{l}\text { Retrospective } \\
\text { (cohort) }\end{array}$ & $\begin{array}{l}421 \text { eyes } \\
\text { (421 patients) }\end{array}$ & $53.1(40-74)$ & $\begin{array}{l}\text { UVL (14) } \\
\text { M: } 12(86 \%) \\
\text { W: } 2(24 \%)\end{array}$ & $1300 \mathrm{cSt}$ & $\begin{array}{l}\text { Giant tear: } 71.4 \% \\
\text { PVR: } 28.5 \%\end{array}$ & 2 years & 141 days (76-218) & $2 b$ \\
\hline
\end{tabular}


Table 1. Main characteristics of the included studies and levels of evidence according to the Oxford Center for Evidence-Based Medicine (OCEBM) ( $\mathrm{n}=13$ ) (continued)

\begin{tabular}{|c|c|c|c|c|c|c|c|c|c|c|}
\hline Studies & Country & Design: & Population & Age & Sex & SO type & Indications for surgery & Follow-up time & SO removal interval & $\begin{array}{l}\text { OCEBM } \\
\text { grading }\end{array}$ \\
\hline $\begin{array}{l}\text { Anaya-Pava, } \\
\text { et al. }{ }^{7} \text { (2017) }\end{array}$ & Mexico & $\begin{array}{l}\text { Retrospective } \\
\text { (cohort) }\end{array}$ & $\begin{array}{l}269 \text { eyes } \\
\text { ( } 235 \text { patients) }\end{array}$ & $\begin{array}{c}\text { M: } 58.6(26-86) \\
\text { W: } 59.7 \\
(24-88)\end{array}$ & $\begin{array}{l}\text { M: } 139 \\
(51.7 \%) \\
\text { W: } 130 \\
(48.3 \%)\end{array}$ & $5000 \mathrm{cSt}$ & $\begin{array}{l}\text { TRD: } 65 \% \\
\text { RRD + PVR: } 32 \% \\
\text { Trauma: } 3 \%\end{array}$ & 5 years & $\begin{array}{l}11 \text { months (1-58) } \\
\text { Trauma: } \bar{X}=11 \\
\text { (3-24 weeks) } \\
\text { PDR: } \bar{X}=10 \text { (5-16 } \\
\text { weeks) } \\
\text { RRD + PVR } \bar{X}=11 \\
\text { (8-19 weeks) }\end{array}$ & $2 b$ \\
\hline $\begin{array}{l}\text { Roca, et al. }{ }^{18} \\
(2017)\end{array}$ & $\begin{array}{l}\text { Argentina } \\
\text { Brazil } \\
\text { Costa Rica } \\
\text { Colombia } \\
\text { United States } \\
\text { Spain } \\
\text { Mexico } \\
\text { Puerto Rico } \\
\text { Venezuela }\end{array}$ & $\begin{array}{l}\text { Retrospective, } \\
\text { multicentric } \\
\text { (cohort) }\end{array}$ & $\begin{array}{l}324 \text { eyes } \\
\text { (324 patients) }\end{array}$ & $\begin{array}{c}\text { UVL: } \\
49.2 \pm 16.4 \\
(16-73)\end{array}$ & $\begin{array}{l}\text { UVL (19) } \\
\text { M: } 8(42 \%) \\
\text { W: } 11(68 \%)\end{array}$ & $\begin{array}{l}1000 \mathrm{cSt} \\
(42.1 \%) \\
5000 \mathrm{cSt} \\
(57.9 \%)\end{array}$ & $\begin{array}{l}\text { DTRD: } 47.4 \% \\
\text { Giant tear: } 10.5 \% \\
\text { PVR: } 31.6 \% \\
\text { RD macula off: } \\
63.2 \%\end{array}$ & 14.8 months & $14.8 \pm 4.4$ months & $2 b$ \\
\hline $\begin{array}{l}\text { Jabbour, } \\
\text { et al. }{ }^{13} \text { (2018) }\end{array}$ & Lebanon & $\begin{array}{l}\text { Prospective } \\
\text { (cohort) }\end{array}$ & $\begin{array}{l}254 \text { eyes } \\
\text { (254 patients) }\end{array}$ & $\begin{array}{c}55.33 \pm 16.29 \\
(8-86)\end{array}$ & $\begin{array}{l}\text { M: } 175 \\
(68.9 \%)\end{array}$ & $\begin{array}{l}1000 \mathrm{cSt} \\
(\mathrm{n}=152) \\
5000 \mathrm{cSt} \\
(\mathrm{n}=102)\end{array}$ & $\begin{array}{l}\text { TRD: } 61.1 \% \\
\text { PVR: } 38.9 \%\end{array}$ & $\begin{array}{c}22.4 \pm 18.1 \\
(6-76 \text { months })\end{array}$ & 6 months & $1 b$ \\
\hline $\begin{array}{l}\text { Abdalkader, } \\
\text { et al. }{ }^{32} \text { (2019) }\end{array}$ & United States & $\begin{array}{l}\text { Retrospective } \\
\text { (cohort) }\end{array}$ & $\begin{array}{l}57 \text { eyes } \\
\text { (57 patients) }\end{array}$ & $\begin{array}{c}\text { Migration } \\
56.1 \pm 16.6 \\
\text { No migration } \\
57.5 \pm 18.6\end{array}$ & $\begin{array}{l}\text { M: } 31(54.4 \%) \\
\text { W: } 26(45.6 \%)\end{array}$ & $\begin{array}{l}1000 / \\
5000 \mathrm{cSt}\end{array}$ & $\begin{array}{l}\text { TRD: } 59,6 \% \text { Trauma: } 7 \% \\
\text { CMV retinitis: } 5.2 \% \\
\text { Glaucoma: } 3.5 \% \\
\text { Postoperative bleeding: } 1.75 \% \\
\text { Congenital infection: } 1.75 \% \\
\text { Unknown: } 21 \%\end{array}$ & $\begin{array}{c}1 \text { month to } 4 \\
\text { years after SO } \\
\text { injection }\end{array}$ & NA & $2 b$ \\
\hline
\end{tabular}

SO: silicone oil; IFB: intraocular foreign body; CMV: cytomegalovirus; cSt: centistokes; DTRD: diabetic tractional retinal detachment; RD: retinal detachment; GT: giant retinal tear; RRD: rhegmatogenous retinal detachment; TRD: tractional retinal detachment; RCT: randomized clinical trial; G1: removal as prevention of complications; G2: removal as a treatment for complications; W: men; W: women; NA: not applicable; NS: not specified; CRVO, central retinal vein occlusion; UVL: unexplained
visual loss; PVR: proliferative vitreoretinopathy; PDR: proliferative diabetic retinopathy. 
Table 2. Frequency of complications after silicone oil use

\begin{tabular}{lc|}
\hline Complication & Median (I0R) \\
\hline Ocular hypertension & $23.3(22.15-35.1 \%)$ \\
\hline Secondary glaucoma & $6(4.5-9.1 \%)$ \\
\hline Pupillary block & $4.3(3.8-4.8 \%)$ \\
\hline Cataracts & $90(80-100 \%)$ \\
\hline Keratopathy & $6.3(4.55-13.9 \%)$ \\
\hline Re-detachment & $22(18.5-30 \%)$ \\
\hline Hypotonia & $13.5(9.55-17.65 \%)$ \\
\hline Expulsive hemorrhage & $1(0.95-1.05 \%)$ \\
\hline Unexplained visual loss & $4.6(3.95-5.25 \%)$ \\
\hline Submacular migration & $8.95(7.42-10.47 \%)$ \\
\hline Rebleeding & $6.1(5.25-6.85 \%)$ \\
\hline Subconjunctival oil deposits & $4.15(3.75-4.57 \%)$ \\
\hline Emulsification in the anterior chamber & $64.5(46.75-82.25 \%)$ \\
\hline IQR: interquartile range. & \\
\hline
\end{tabular}

\section{Discussion}

It is known that most of the indications for the use of SO are complex retinal detachments, such as PVR, GT, PDR, TRD or due to trauma or viral infection ${ }^{1-25}$. In these cases, OS is very useful to maintain adhesion between the retina and the retinal pigment epithelium and reduce the risk of reRD; however, it is known that its use as tamponade can be associated with several complications that must be considered in the follow-up of these patients ${ }^{10-17}$.

One of the most common complications is cataract formation, which may occur de novo or from an existing opacity ${ }^{18}$. Cataract formation is observed in $100 \%$ in some series at 5 years of follow-up ${ }^{8}$, and the incidence is related to the duration of intraocular SO. Ultrastructural studies have shown alterations in lens epithelial cells ${ }^{7-9}$. Cataracts are also a cause of low vision and its removal should be scheduled at the same time of SO removal, considering the corneal endothelial cell count, which could be altered by the effect of SO ${ }^{23-34}$. In our review we found that this is the main complication reported. Its dispersion is wide and is directly related to the time the SO remained in the cavity, as there are studies that follow-up during 5 years and others monitor a shorter interval ${ }^{18}$.

Secondary glaucoma and OHT have also been reported as frequent complications, with rates of $3-7.8 \%$ for glaucoma $\mathrm{m}^{7-10}$ and $11-46.6 \%$ for $\mathrm{OHT}^{10-22}$. Associated risk factors are pseudophakia, aphakia, high myopia, previous $\mathrm{OHT}$, and the use of low-viscosity $\mathrm{SO}^{12}$. Cases of pupillary block have also been described, which should be managed with an inferior peripheral iridotomy with Nd-YAG laser or by reopening a pre-existing occluded iridotomy. Many of these patients improve when the SO is removed, but $6.8 \%$ will need filtering surgery to control intraocular pressure ${ }^{12}$. It is important before surgery with SO injection to tell patients about the possibility of developing $\mathrm{OHT}$ and, therefore, the need for prolonged topical treatment, or even surgical procedures if this complication continues postoperatively ${ }^{12}$. Our study shows the high frequency of this complication, and its wide dispersion correlates in part with the methodology used to define OHT in the different studies and with the treatment that the patients received.

reRD rates vary widely, between $14 \%{ }^{14}$ and $50 \%{ }^{15}$; this variation depends on the characteristics of the retinal detachment and the underlying pathology. Most studies, almost all retrospective in nature, describe that the highest rate of reRD occurs in the first postoperative days. The factor most frequently associated with reRD is PVR; the larger and more anterior the PVR, the greater the risk of reDR. Other causes of reRD are PDR with TRD, GT and those associated with trauma ${ }^{16-19}$. When analyzing the values found in the literature, we observed a great dispersion regarding this complication (IQR: 18.5-30\%). It should be mentioned that reRD has been studied more than other complications, considering the surgical indication of these patients (complex detachments), which also contributes to its numerical expression as one of the primary associated complications.

Hypotonia after SO removal was described in 5.2$22.5 \%$ of cases $^{21}$. Studies show that it occurs more frequently in patients with postoperative retinal detachment with macular involvement, and the mechanism would not only depend on the indication for surgery, but would also be associated with an alteration of the ciliary body and anterior chamber inflammation ${ }^{21}$.

Unexplained visual loss is a clinical challenge, as many patients may have lower-than-expected best-corrected visual acuity after SO removal without a demonstrable anatomic cause. More and more cases have been described and their cause is not fully understood $^{25-29}$. The pathogenic mechanisms suggested are direct macular dysfunction caused by contact with $\mathrm{SO}$, alterations in growth factors and foveal phototoxicity ${ }^{4-25,28}$. Many authors believe that OHT could be associated, but there are no studies with a robust methodology 
to confirm any of these theories. Rates range from 3.3\% to $5.9 \%$ of cases $^{15-32}$.

Considering all the available information on the possible complications after $\mathrm{SO}$ injection and its association with the duration of intraocular SO, the question arises about the appropriate timing for SO removal; however, there is no established consensus to date, since many of these patients have complex pathologies with an unpredictable course. Although SO is an excellent longterm retinal tamponade, its use should be temporary due to the complications observed after prolonged use. An important event is the emulsification of SO; the longer the intraocular duration, the greater the probability of emulsification ${ }^{15-35}$. One study found that the average time for SO emulsification to occur after surgery is 13 months ${ }^{33}$. The available evidence does not allow us to answer the question about the optimal time for SO removal, so it is suggested that it should be individualized in each patient; however, most authors agree on a minimum of 3 to 6 months of tamponade ${ }^{12-33}$.

Regarding the limitations of the study, due to the heterogeneity of the articles included, it was not possible to perform a meta-analysis to consolidate the available information. As a result of our inclusion criteria and study methodology, other relevant publications may have been omitted; to minimize this, we performed the evaluation by three authors separately and then together.

In conclusion, the most frequent complications reported were, in decreasing order, cataracts, anterior chamber oil emulsification, $\mathrm{OHT}$, reRD, keratopathy, hypotonia, subretinal SO migration, rebleeding, secondary glaucoma, unexplained visual loss, pupillary blockage, conjunctival deposits of SO and expulsive hemorrhage.

\section{Conflicts of interest}

The authors declare no conflicts of interest.

\section{Ethical disclosures}

Protection of human and animal subjects. The authors declare that no experiments were performed on humans or animals for this study.

Confidentiality of data. The authors declare that they have followed the protocols of their Institution on the publication of patient data.

Right to privacy and informed consent. The authors declare that no patient data appear in this article.

\section{References}

1. Stone W. Alloplasty in Surgery of the Eye. New Engl J Med. 1958;258:486.

2. Cibis PA, Becker B, Okun E, Cannan S. The use of liquid silicone in retinal detachment surgery. Arch Ophthalmol. 1962;68:590-9.

3. Gallemore RP, McCuen BW II. Silicone oil in vitreoretinal surgery. En: Ryan SJ, editor. Retina. 4th ed. Philadelphia: Elsevier Mosby; 2006. p. 2211-34.

4. Barca F, Caporossi T, Rizzo S. Silicone oil: different physical proprieties and clinical applications. Biomed Res Int. 2014;2014:502143.

5. Joussen AM, Wong D. The concept of heavy tamponades-chances and limitations. Graefes Arch Ophthalmol. 2008;246:1217-24.

6. Ryan SJ. Silicone oils: physicochemical properties. En: Rayan SJ, editor. Retina. 4th ed. Philadelphia: Elsevier Mosby; 2006. p. 2191-210.

7. Anaya-Pava EJ, Sáenz-Bocanegra CH, Baeza García JA, Rodríguez V. Estudio retrospectivo de complicaciones asociadas al aceite de silicona. Experiencia de 5 años en un hospital público del norte de México. Rev Mex Oftal. 2017;91:76-81.

8. Zhu L, Zhao K, Lou D. Apoptosis factors of lens epithelial cells responsible for cataractogenesis in vitrectomized eyes with silicone oil tamponade. Med Sci Monit. 2016;22:788-96.

9. Soliman W, Sharaf M, Abdelazeem K, El-Gamal D, Nafady A. Ultrastructural effects of silicone oil on the clear crystalline lens of the human eye. Eur J Ophthalmol. 2018;28:566-72.

10. Casswell AG, Gregor ZJ. Silicone oil removal. II. Operative and postoperative complications. Br J Ophthalmol. 1987;71:898-902.

11. Franks WA, Leaver PK. Removal of silicone oil - rewards and penalties. Eye (Lond). 1991;5(Pt 3):333-7.

12. Falkner $\mathrm{Cl}$, Binder $\mathrm{S}$, Kruger $\mathrm{A}$. Outcome after silicone oil removal. $\mathrm{Br} \mathrm{J}$ Ophthalmol. 2001;85:1324-7.

13. Jabbour E, Azar G, Antoun J, Kourie HR, Abdelmassih Y, Jalkh A. Incidence and risk factors of ocular hypertension following pars plana vitrectomy and silicone oil injection. Ophthalmologica. 2018;240:129-34.

14. Hutton WL, Azen SP, Blumenkranz MS, Lai MY, McCuen BW, Han DP, et al. The effects of silicone oil removal. Silicone Study Report 6. Arch Ophthalmol. 1994;112:778-85.

15. Federman JL, Schubert HD. Complications associated with the use of silicone oil in 150 eyes after retina-vitreous surgery. Ophthalmology. 1988;95:870-6.

16. The Silicone Study Group. Vitrectomy with silicone oil or sulfur hexafluoride gas in eyes with severe proliferative vitreoretinopathy: results of a randomized clinical trial. Silicone Study Report 1. Arch Ophthalmol. 1992;110:770-9

17. Scholda C, Egger S, Lakits A, Walch K, von Eckardstein E, Biowski R. Retinal detachment after silicone oil removal. Acta Ophthalmol Scand. 2000;78:182-6.

18. Roca JA, Wu L, Berrocal M, Rodriguez F, Alezzandrini A, Alvira G, et al. Un-explained visual loss following silicone oil removal: results of the Pan American Collaborative Retina Study (PACORES) Group. Int J Retina Vitreous. 2017;3:26.

19. Scheerlinck LM, Schellekens PA, Liem AT, Steijns D, van Leeuwen R. Incidence, risk factors, and clinical characteristics of unexplained visual loss after intraocular silicone oil for macula-on retinal detachment. Retina. 2016;36:342-50.

20. Moya R, Chandra A, Banerjee PJ, Tsouris D, Ahmad N, Charteris DG. The incidence of unexplained visual loss following removal of silicone oil. Eye (Lond). 2015;29:1477-82.

21. Winter M, Eberhardt W, Scholz C, Reichenbach A. Failure of potassium siphoning by Müller cells: a new hypothesis of perfluorocarbon liquid-induced retinopathy. Invest Ophthalmol Vis Sci. 2000;41:256-61.

22. Christensen UC, La Cour M. Visual loss after use of intraocular silicone oil associated with thinning of inner retinal layers. Acta Ophthalmol. 2012;90:733-7.

23. Szaflik JP, Kmera-Muszyńska M. Confocal microscopy imaging of the cornea in patients with silicone oil in the anterior chamber after vitreoretinal surgery. Graefes Arch Clin Exp Ophthalmol.2007;245:210-4.

24. Legler U, Seiberth V, Knorz MC, Jung E. [Loss of corneal endothelial cells following pars plana vitrectomy and silicone oil implantation]. Fortschr Ophthalmol. 1990;87:290-3.

25. Kuhn F, Kover F, Szabo I, Mester V. Intracranial migration of silicone oil from an eye with optic pit. Graefes Arch Clin Exp Ophthalmol. 2006;244:1360-2.

26. Michel G, Meyer L, Naoun O. [Sudden visual loss following silicone oil removal: three patients treated for giant retinal tear]. J Fr Ophtalmol. 2009;32:104-11.

27. Winter M, Eberhardt W, Scholz C, Reichenbach A. Failure of potassium siphoning by Müller cells: a new hypothesis of perfluorocarbon liquid-induced retinopathy. Invest Ophthalmol Vis Sci. 2000;41:256-61.

28. Asaria $\mathrm{RH}$, Kon $\mathrm{CH}$, Bunce $\mathrm{C}$, Sethi CS, Limb GA, Khaw PT, et al. Silicone oil concentrates fibrogenic growth factors in the retro-oil fluid. $\mathrm{Br} J$ Ophthalmol. 2004;88:1439-42. 
Rev Mex Oftalmol (Eng). 2021;95(2)

29. Cazabon S, Groenewald C, Pearce IA, Wong D. Visual loss following removal of intraocular silicone oil. $\mathrm{Br}$ J Ophthalmol. 2005;89: 799-802.

30. Jiang F, Krause M, Ruprecht KW, Hille K. Risk factors for anatomica success and visual outcome in patients undergoing silicone oil removal. Eur J Ophthalmol. 2002;12:293-8.

31. Riedel KG, Gabel VP, Neubauer L, Kampik A, Lund OE. Intravitreal silicone oil injection: complications and treatment of 415 consecutive patients. Graefes Arch Clin Exp Ophthalmol. 1990;228:19-23.

32. Abdalkader M, Takumi K, Chapman MN, Barest GD, Peeler C, Sakai O Subretinal and retrolaminar migration of intraocular silicone oil detected on CT. AJNR Am J Neuroradiol. 2019;40:1557-61.
33. Toklu Y, Cakmak HB, Ergun SB, Yorgun MA, Simsek S. Time course of silicone oil emulsification. Retina. 2012;32:2039-44.

34. Satchi K, Bolton A, Patel CK. Loss of vision once silicone oil has been removed. Retina. 2005;25:807-8.

35. Miller JB, Papakostas TD, Vavvas DG. Complications of emulsified silicone oil after retinal detachment repair. Semin Ophthalmol. 2014;29:312-8.

36. Lucke $\mathrm{KH}$, Foerster $\mathrm{MH}$, Laqua $\mathrm{H}$. Long-term results of vitrectomy and silicone oil in 500 cases of complicated retinal detachments. Am J Ophthalmol. 1987; 104:624-33.

37. Moher D, Liberati A, Tetzlaff J, Altman DG; PRISMA Group. Preferred reporting items for systematic reviews and meta-analyses: the PRISMA Statement. PLoS Med. 2009;6:e1000097. 